\title{
Field trial of an automated batch chlorinator system at two shared shallow tubewells among camps for forcibly displaced Myanmar nationals (FDMN) in Cox's Bazar, Bangladesh
}

\section{Nuhu Amin ( $\nabla$ nuhu.amin@icddrb.org )}

Environmental Interventions Unit, International Centre for Diarrhoeal Disease Research Bangladesh (icddr,b), Dhaka https://orcid.org/0000-0002-7131-6163

\section{Mahbubur Rahman}

Environmental Interventions Unit, International Centre for Diarrhoeal Disease Research Bangladesh (icddr,b)

\section{Mahbub-Ul Alam}

Environmental interventions Unit, International center for Diarrhoeal Diseases and Research Bangladesh (icddt,b), Dhaka)

\section{Abul Kasham Shoab}

Environmental Interventions Unit, International Centre for Diarrhoeal Disease Research Bangladesh (icddr,b), Dhaka

\section{Md. Kawsar Alome}

Action Against Hunger (ACF)

\section{Maksudul Amin}

Action Against Hunger

\section{Tarique Mohammad Nurul Huda}

Environmental Interventions Unit, International Centre for Diarrhoeal Disease Research Bangladesh (icddr,b), Dhaka

\section{Leanne Unicomb}

Environmental Interventions Unit, International Centre for Diarrhoeal Disease Research Bangladesh (icddr,b), Dhaka

\section{Research Article}

Keywords: cholera, non-governmental organizations, international agencies, local businesses, philanthropists rapidly

Posted Date: February 9th, 2021

DOI: https://doi.org/10.21203/rs.3.rs-217245/v1

License: (c) (i) This work is licensed under a Creative Commons Attribution 4.0 International License. Read Full License

Version of Record: A version of this preprint was published at International Journal of Environmental Research and Public Health on December 8th, 2021. See the published version at https://doi.org/10.3390/ijerph182412917. 


\section{Abstract}

Background: There are considerable benefits of point-of-use water chlorination programmes in emergencies but remaining challenges include lack of standard dosing recommendations for water treatment, inappropriate chlorination technologies, and limited published evaluations. We conducted a small-scale before-and-after field trial to assess the accuracy and consistency of an automated chlorinator named Zimba in camps housing forcibly displaced Myanmar nationals (FDMN), Cox's Bazar.

Methods: From August-September 2018, we selected two shallow tubewells [one with high $(6.5 \mathrm{mg} / \mathrm{L})$ and one with low $(1.5 \mathrm{mg} / \mathrm{L})$ iron concentration), and enrolled 20 households (10 having access to each tubewell) to participate in household surveys and water sampling. At baseline, field-team tested tubewell, and household stored water for iron, turbidity, free and total chlorine from using digital field-test kits. At baseline, the team collected water samples from selected tubewells $(\mathrm{N}=2)$, from Zimba chlorinators immediately after chlorination. $(\mathrm{N}=8)$ and household stored drinking water $(\mathrm{N}=20)$. Over four weeks, they collected post-treated water stored in household vessels $(\mathrm{N}=84)$, and post-treated household stored water in a project provided safe storage container $(\mathrm{N}=15)$. Water samples were tested for $\mathrm{E}$. coli. Results: At baseline, $12(60 \%)$ samples of water stored in household vessels were contaminated with E. coli (mean $\log 10 \mathrm{E}$. coli=0.62 MPN/100mL). After installing the Zimba, all water samples (100\%) collected immediately after chlorination and project provided safe storage containers were free from E. coli, but $41 \%$ of post-treated water stored in household were contaminated with at least one E. coli/100mL. Log10 mean E. coli concentrations storage containers water stored in household vessels at baseline were similar to the post-treated water stored in the household vessels. E. coli concentrations were significantly lower in the project-provided safe storage containers [( $\log 10$ mean difference $=0.92 \mathrm{MPN}$, $95 \% \mathrm{Cl}$ 0.59-1.14)] compared to baseline and to post-treated water stored in household vessels [( $\log 10$ mean difference $=0.57 \mathrm{MPN}$, $95 \% \mathrm{Cl} 0.32-0.83)$ ]. Conclusions: The Zimba is a potential water treatment technology for groundwater extracted through tubewells with different iron concentrations in humanitarian settings. Future research should address the low chlorine residual in household stored water and its impact on water contamination.

\section{Background}

As of 2015, globally, at least two billion people acquire drinking water from faecal-contaminated sources (WHO 2018), responsible for approximately 502,000 deaths each year (1). Faecal contaminated water has substantial negative health impacts, particularly in humanitarian and/or emergency settings with crowded spaces and limited access to safe drinking water. Studies conducted during the refugee crisis in the Democratic Republic of Congo in 1994 following an influx of more than 800,000 refugees from Rwanda suggested that water-related pathogens (e.g., cholera) were responsible for about $85 \%$ of the 50,000 deaths in refugee camps $(2,3)$.

Since 25 August 2017, an estimated 815,280 Myanmar nationals have been forced to flee their native land to escape extreme violence and persecution and settled in Cox's Bazar, Bangladesh $(4,5)$. To ensure availability of drinking water, several nongovernmental organizations, international agencies, local businesses, and philanthropists rapidly installed approximately 20,000 tubewells in camps housing forcibly displaced Myanmar nationals (FDMN) (6). Several studies suggest that shallow tubewells can be the source of water-related outbreaks and diseases due to high-level microbial contamination (7-9). A recent report found that of up to 14,522 samples from tubewells in FDMN-camps, $47 \%$ were contaminated with faecal coliforms and $21 \%$ with $E$. coli. In comparison to tubewell water, the contamination level of household stored water, or point-of-use (POU) water sample contamination was higher ( $74 \%$ contaminated with faecal coliforms and $35 \%$ with $E$. coli) (10). In a further study in FDMN-camps, among 384 samples from shallow tubewells, more than $17 \%(n=66)$ were positive for antimicrobially resistant $E$. coli and $7 \%(n=$ 29) were positive for at least one virulence factor of E. coli (9).

Point-of-use (POU) chlorination is common in humanitarian settings due to the availability of chlorine products, ease of use, costeffectiveness, efficacy in inactivating viral and bacterial pathogens, and maintenance of chlorine residual in treated water that protects against recontamination during storage (11). However, regardless of substantial benefits, successful chlorination program in humanitarian settings remain challenging primarily for the following reasons: 1 ) there is no standard recommendation for chlorine dosing or residual chlorine levels in emergency settings from the WHO or the Environmental Protection Agency of the United States of America (12), 2) programmatic elements such as distribution, promotion, and supply chain cannot necessarily be generalized to different types of emergencies or geographic and cultural settings, 3) wide variation in the chemical composition of supplied (ground/surface) water (13-15); and 4) perception of unpleasant taste and/or smell of water treated with chlorine

Page $2 / 21$ 
products differs globally (18). POU chlorination methods require optimization of chlorine required for customized dosage volumes represented by various household storage container sizes (i.e., for $5 \mathrm{~L}, 10 \mathrm{~L}$ or $20 \mathrm{~L}$ ), $(16,17)$. Previous studies from Bangladesh suggested that the taste and smell of chlorine in water, the time required for daily water treatment, personal motivation, knowledge, and behavior change are considerable barriers to POU treatment uptake resulting in inconsistent and inaccurate practices $(15,18$, 19).

Few drinking water chlorination technologies are available that overcome some of the challenges of POU water treatment in lowincome communities (20-22). In 2012 we conducted a small-scale field trial to explore the accuracy, consistency, and acceptability of an automated chlorinator named Zimba in a low-income urban slum of Dhaka (22). Zimba, which is attached to the source (i.e., tubewell), automatically treats water with chlorine and was shown to save time and effort and minimized the chance of chlorine dosage errors (22). Despite Zimba's success in Dhaka, there is a lack of research on how Zimba performs treating water extracted by manual underground shallow tubewell with different iron levels, total dissolved solids (TDS), and water turbidity, and none from humanitarian settings.

We conducted a small-scale field trial with the individual tubewell automated chlorinator unit, Zimba, in two FDMN-camps, Cox's Bazar, which has the potential to overcome some POU treatment barriers (22). Zimba disburses a preset dose of three $\mathrm{ml}$ of hypochlorite or bleach $(\mathrm{NaOCl})$ solution for every $10 \mathrm{~L}$-batch of water into a mixing chamber. Water is flushed immediately after chlorination by a mechanical siphon into a storage tank and dispensed by a tap (Figure S1) (22). Zimba units do not need specialist engineering for installation and can be adapted to traditional tubewells from which households can draw a small amount of treated water. In this trial, we assessed $E$. coli concentration in untreated tubewell water, pre-intervention water stored in the household vessels, treated Zimba water directly from the Zimba storage tank (immediately after treatment), post-treated water stored in the household vessels and project provided safe storage containers at households. We explored the chlorination accuracy and consistency of Zimba, along with community acceptability. We also compared the efficacy of Zimba to deliver adequate chlorine residual in tubewell water with different iron concentrations.

\section{Methodology}

\section{Study design}

The study was conducted in August and September 2018 (during monsoon season) in two FDMN-camps in Kutupalong, Cox's Bazar. We selected Camp-1 and Camp-2, where both the longer-term and recently arrived FDMN population lived together (Figure S2). One of the investigators (NA), along with the field research team, conducted initial scoping visits to the selected camps and performed preliminary water quality assessments measuring iron, turbidity, and total dissolved solids (TDS) using digital field-test kits. They selected two shallow tubewells from each camp with different water physicochemical properties: tubewell ID-13 and tubewell ID-17 from Camp-1 and tubewell ID-2 and tubewell ID-5 from Camp-2.

The FDMN-camps in our study area consisted of multiple households with shared toilets, bathing spaces, and drinking water sources owned by the Government of Bangladesh and managed by humanitarian agencies and WASH sector coordinators Cox's Bazar. Groundwater was extracted through shallow tubewells (< 76-meter depth) and maintained by Action Against Hunger (ACF). Each tubewell (water collection point) was located within an accessible distance (i.e., within 5-minute walk) for multiple households and was used for drinking and other household purposes. Water points were selected based on the following eligibility criteria: (1) water point shared by 100 households (2) water extracted by a manual underground shallow tubewell, (3) the tubewells were the primary drinking water source for the families/users, and (4) had sufficient space around the platform of the tubewell for Zimba installation. There was no active chlorination project in place when enrolling the study participants. Although there was no active water treatment program in our selected neighborhoods, a small number of households had chlorine tablets [e.g., Aquatab (Medentech, Inc, Wexford, Ireland)] supplied by NGOs.

\section{Field team}

There were two assigned teams for this study, the field research team and the sample collection team. The field research team conducted surveys and community sessions. The team consisted of experienced staff who were fluent in Bengali and Rakhine 
language (the mother language spoken by the FDMN). The sample collection team consisted of trained staff responsible for water sample collection.

The survey team used convenience sampling to select ten households adjacent to each tubewell to participate in household surveys. Households who reported that they collected water from the intervention tubewells were prioritized for household surveys. The team visited and provided information on Zimba, described the study activity with household members using cue cards and other visual aids, and obtained their written informed consent in Bengali and Rakhine. They surveyed households at baseline, immediately after Zimba installation chlorine treatment of the primary tubewells, and at end-line, after four weeks of intervention (Figure S3). Mothers with at least one child less than five years of age were given enrollment preference in the surveys.

\section{Baseline, follow-up and end-line data collection}

We collected data on demographics, water collection and storage practice, drinking water treatment method, and perception of existing camp water supply.

The survey team conducted twice a week follow-up visits to the selected households. They collected water samples directly from the Zimba, and household storage containers after treatment. They performed hourly tests of immediately treated Zimba water every day for eight hours to ensure the source's chlorine dosing accuracy.

Within seven days of Zimba installation, the survey team conducted short surveys with the study participants to assess immediate acceptability, satisfaction, and problems they were facing with the Zimba. The team tried to address the problems (i.e., increased height of the hand pump, smell/taste of chlorine and queuing while collecting water) raised by the users in subsequent weeks. At the end of the 4th week of intervention, 20 intervention household members were interviewed during the end line survey. The survey team used convenience sampling to select one household member involved in regular water management activities for the end line. Household surveys were conducted to collect household demography, drinking water quality satisfaction and perception, water collection, storage practice, and treatment methods.

A total of 10 in-depth interviews (IDIs) were conducted with the study participants other than those participating in baseline surveys from among enrolled households ( 5 from each site) to understand their views and beliefs on Zimba water. One member of the survey team, along with a local Rakhine interpreter to conduct IDIs. Each of the interviews focused on Zimba's user perception, frequency of drinking from Zimba, perceptions (likes/dislikes and advantages/disadvantages/limitations) of treated water, and Zimba chlorination device, changes in taste and/or smell, and perception of treated water over the study period. Study participants were also asked their opinions on how the Zimba device could be improved.

\section{Intervention components}

\section{Chlorine purchase, dilution, and dose adjustment}

The sample collection team purchased household chlorine bleach ( 5.25\% NaOCl: Clorox ${ }^{\circledR}$ : the Clorox Company, Oakland, CA, USA) from the market near the Cox's Bazar field office. They diluted the raw chlorine in tap water (mean iron concentration $<0.02$ $\mathrm{mg} / \mathrm{L}$, mean turbidity 3.7= Nephelometric Turbidity Unit (NTU) and mean TDS=10 ppm) to $3.5 \% \mathrm{NaOCl}$ to attain $\sim 2 \mathrm{mg} / \mathrm{L}$ of free residual chlorine in household stored water within 24 hours of treatment, which they added to Zimba. This process of optimization was checked for each of the tubewells (Table S1) (23). The team tested the concentration of chlorine (NaOCl) solution with the colorimeter each time they refilled the Zimba. We subsequently reduced the $\mathrm{NaOCl}$ concentration to $2.85 \%$ for high iron content tubewell water and $2.25 \%$ for low iron content tubewell water to attain treated water with $\sim 1.5 \mathrm{mg} / \mathrm{L}$ of free residual chlorine.

\section{The Zimba device and its installation:}

The descriptions of the Zimba and installation steps were reported previously for the urban Dhaka Zimba trial (22). In brief, the Zimba is made of fiberglass. It has three components:

- a dispenser containing diluted bleach $(\mathrm{NaOCl})$

- a dosing chamber containing a siphon 
- an outer box that holds the siphon tank and the dispenser

The production cost of Zimba is estimated at around 200 USD, including installation. The Zimba does not have any mobile component and does not require any power source. The Zimba is mounted on a customized plastic stand approximately $30 \mathrm{~cm}$ in height (Figure S1). Two hand-pump mechanics from ACF installed the Zimba under the supervision of icddr,b. We also trained four ACF fieldworkers on regular chlorine refilling and maintenance of the Zimba so that it could be used after the intervention period.

\section{Water storage containers:}

During the first follow-up visit, the survey team provided a new $5 \mathrm{~L}$ plastic jerrycan of Zimba chlorinated water (mean residual chlorine at time of distribution=1.4 mg/L) with an airtight lid as a control. The day prior to collecting household stored treated water, the field research team refilled the jerrycan and provided it at the respondent's household. The field research team encouraged the household members to drink water from the jerrycan and to keep the lid close after use. The field research team also requested the respondents to retain some water ( one glass) in the jerrycan to be collected the next day. This was done to determine if the current household water storage practices impacted the chlorine treatment programme.

\section{Intervention delivery}

We used a similar approach for promoting the Zimba as the urban Dhaka trial (22). The day before Zimba installation, the survey team held a meeting with the camp Majhi (local FDMN leader), a local volunteer, and all study participants from the household and introduced water treatment with chlorine and potential health impacts. Zimba usage was explained using flip charts. The survey team requested that the Majhi and study participants share and discuss this information with other household members.

\section{Tubewell and household stored water testing}

The sample collection team tested the tubewell and stored water samples from all enrolled households for iron, using an iron meter: (Hach color disk test kit, Model IR-18B, Hack Company, Loveland, Colorado), TDS using a pocket TDS meter (Hanna instruments, Business Park Dr. Vista, California), turbidity, free and total chlorine level in collected water using a digital turbidity meter (LaMotte Model 2020i, LaMotte Company, Chestertown, Maryland) and Colorimeter (LaMotte Model 1200, LaMotte Company, Chestertown, Maryland). Using $100 \mathrm{~mL}$ sterile sample collection bags, the sample collection team collected tubewell and water samples stored in all selected households (Nasco Whirl-Pak®, 19 x $38 \mathrm{~cm}$, Fort Atkinson, Wisconsin). Collected samples maintained at a temperature of $<10^{\circ} \mathrm{C}$ through primary storage in cold boxes with ice packs were sent to the ACF field laboratory at Cox's Bazar for E. coli contamination assessment.

\section{Water sample laboratory analysis}

After measuring the physiochemical (iron, TDS, water turbidity, and free and total residual chlorine) property of each sample, the sample collection team collected four types of water samples: untreated tubewell water, pre-intervention water stored in the household vessel, treated Zimba water directly from the Zimba storage tank (immediately after treatment), post-treated water stored in the household vessel and project provided safe storage containers at households. Post-treated water samples were collected at two-time points: twice-weekly follow-up visits and during end-line surveys.

All samples were received within 6 hours of collection by the laboratory technician and quantified the most probable number (MPN) of E. coli per $100 \mathrm{~mL}$ of a water sample using the IDEXX- Quanti-tray ${ }^{\circledR} 2000$ technique with Colilert-24 media (IDEXX Laboratories, Westbrook, Seattle, WA) (24). In recent water treatment efficacy trials, E. coli was most commonly used as an indicator of faecal microbial contamination in drinking water samples $(21,25,26)$. All water samples were processed on the same day; the laboratory supervisor pre-tested two different dilutions [undiluted (1:1) and 1:10] of water samples to determine the ultimate dilution factor to minimize undetectable samples with $E$. coli or $E$. coli concentrations exceeding the upper detection limit (27). Due to the low water contamination level found during the initial laboratory analysis, all drinking water samples (both tubewell and household stored water) were analyzed without dilution. We used $>1$ to $<=2419.6$ MPN detectable range per tray to detect positive E. coli wells within the IDEXX Quanti-Tray (27). 
During each day of sample collection, the fieldworkers collected one field blank of distilled water from the ACF laboratory and then tested on the same day with other water samples in the laboratory for E. coli, and if we found any growth in the field blank, we reinforced aseptic precautions for subsequent sample collection. The laboratory technician proceeds one laboratory blank per day and one negative control (distilled water) per batch of Colilert per day for quality control. Only $3 \%(1 / 30)$ of the tested blanks and $3 \%(1 / 30)$ negative control had E. coli growth. Finally, the laboratory technician processed and sealed the samples in a Quanti-Tray and incubated them at $37^{\circ} \mathrm{C}$ for 24 hours. The laboratory technician determined the MPN of $E$. coli by counting the number of fluorescing wells and calculating according to the manufacturer's instructions. We reported all water samples as MPN of $E$. coli/100 mL

\title{
Quantitative data analysis
}

We estimated the value of 0.5 MPN for samples below the detection limit and 2419.6 MPN for samples above the detection limit. We compared E. coli contamination and water parameters (iron, TDS, water turbidity, and free and total chlorine) between pretreated water to post-treated household storage containers, using generalized linear regression models. We also compared levels of iron, free and total chlorine for baseline stored water vs. post-treated household storage containers, baseline stored water vs. post-treated project provided safe storage container, and post-treated household storage containers vs. post-treated project provided safe storage container and using generalized linear regression model, adjusted for clustering at the households with a robust standard error of the mean difference.

\section{Qualitative data analysis}

The survey team and local FDMN interpreters recorded interviews, downloaded, translated, and transcribed them into Bengali, followed by performed thematic content analysis. The investigator N.A. went through the translations and coded the transcripts according to our research objectives manually. After coding, the investigator thematically categorized the data and matched themes to factors influencing acceptability, feasibility, and chlorine smell and/or taste.

\section{Results}

\section{Baseline characteristics}

\author{
Physiochemical properties of water from 4 selected tubewells
}

Wide variations of iron concentrations were found in four selected tubewell water [mean iron concentration in tubewell ID-13 was $6.5 \mathrm{mg} / \mathrm{L}$ (range: $6.5-6.5 \mathrm{mg} / \mathrm{L}$ ), $7.5 \mathrm{mg} / \mathrm{L}$ (range: $7.5-7.5 \mathrm{mg} / \mathrm{L}$ ) in tubewell ID-2, $1.5 \mathrm{mg} / \mathrm{L}$ (range: $1.5-1.5 \mathrm{mg} / \mathrm{L}$ ) in tubewell ID-17 and tubewell ID-5]. Overall turbidity (mean $<5$ NTU) and TDS (mean $<500$ ppm) concentrations were low in all four selected tubewell water. TDS concentrations were higher in tubewell ID-2 [TDS=380 ppm (range: 355-410 ppm)] compared to tubewell ID-17 [TDS=75 ppm (range: 55-90 ppm)] and tubewell ID-5 [TDS=155 ppm (range: 135-177 ppm)].

\section{Demographic and socioeconomic status}

Among the households enrolled in baseline and end-line surveys $(\mathrm{N}=20)$, the mean age of the respondents was 37 years, and most (70\%) did not have formal education. Each household consisted of 6 members on average, with at least two $<5$-year-old children and an average monthly income of US $\$ 68$. Only two households reported no income source for their family, and others were involved in either small business, daily labor and/or worked at NGOs (Table 1).

\section{Water collection and storage practice}

All respondents reported that water was available 24 hours a day at their tubewells. Most households (60\%) collected their drinking water in a Kolshi(traditional metal pot, $5 \mathrm{~L}$, and $10 \mathrm{~L}$ ) and only $30 \%$ of stored drinking water was observed fully covered with a solid lid. Almost all households were satisfied with the untreated water supply, including water availability, water quality, and water taste/smell (Table 1). About half of the respondents heard about water treatment "using a medicine and/or using 
tablets," but only one mentioned the name "chlorine". One respondent reported a chemical/medicinal smell in their drinking water. At baseline, a few respondents said that they collected drinking water from multiple tubewells if their primary tubewell was broken.

\section{Household stored water quality}

At baseline, before installing the Zimba, stored water samples in $3(15 \%)$ households had detectable free residual chlorine within or above the WHO recommended standard $(0.2-2.0 \mathrm{mg} / \mathrm{L})$. However, the mean free residual concentration was low (mean free residual chlorine concentration $=0.15 \mathrm{mg} / \mathrm{L}, \mathrm{SD}=0.39$ ). In household storage containers, the mean iron concentration was 2.25 $\mathrm{mg} / \mathrm{L}$, and $25 \%$ of households had high iron concentration $(>5 \mathrm{mg} / \mathrm{L})$. The mean turbidity of water in household storage containers was $2.45 \mathrm{NTU}$, and the mean TDS was $338 \mathrm{ppm}$. Concentration of iron in the source tubewell (ID-13) in camp-1 was 6.5 $\mathrm{mg} / \mathrm{L}$ and $1.5 \mathrm{mg} / \mathrm{L}$ for camp-2 (tubewell ID-5) (Table 1). All water samples collected directly from tubewells before treatment were free from $E$. colicontamination. At baseline, $12(60 \%)$ water samples in household storage containers were contaminated with $E$. coli, and the mean $\log _{10}$ E. coliconcentration was 0.62 MPN (SD 0.9) (Table 2).

Two out of four installed Zimba chlorinators (installed at tubewell ID-2 and tubewell ID-17) were taken out from the study and were not included in the analysis. Tubewell ID-2 had a very high $(7 \mathrm{mg} / \mathrm{L})$ concentration of iron, exerting a chlorine demand that prevented the Zimba from providing water with sufficient residual chlorine ( $\leq 0.04 \mathrm{mg} / \mathrm{L})$ immediately after treatment over two consecutive days (Table S1). Additionally, the water turned a red color after treatment due to a chemical reaction between iron and chlorine immediately after mixing. Tubewell ID-17 became too tight to pump water (due to an increase in the height of the barrel of the handpump) after installation of the Zimba. We received complaints from household users that they were unable to pump water. Only three water samples in household storage containers had detectable free residual chlorine ( $>0.20 \mathrm{mg} / \mathrm{L})$, so we used sample collection bags without sodium thiosulfate tablets during water sample collection (22).

\section{Follow-up and end-line visits}

Turbidity and TDS were low and within WHO-recommended acceptable limits $(28,29)$ in all tubewells and stored water samples. All household stored water samples had $<5$ NTU turbidity, and more than $60 \%$ of water samples had less than 300 ppm TDS. Overall mean iron concentrations were $5.8 \mathrm{mg} / \mathrm{L}$ in Zimba water, $1.9 \mathrm{mg} / \mathrm{L}$ in household storage containers, and $2.8 \mathrm{mg} / \mathrm{L}$ in the project provided safe storage containers (Table 2).

All post-chlorination Zimba water samples (100\%) were within or above the WHO recommended free residual chlorine level (0.2-2.0 $\mathrm{mg} / \mathrm{L}=50 \%,>2 \mathrm{mg} / \mathrm{L}=50 \%$ ) (Mean= $2.1 \mathrm{mg} / \mathrm{L}, \mathrm{SD}=1.1$ ) and total chlorine (mean=2.21 mg/L, $\mathrm{SD}=0.95$ ). When comparing water characteristics before installing the Zimba, we found significant differences in chlorine concentrations between baseline, posttreated water from household storage containers and project provided safe storage containers. Mean concentration of free and total chlorine levels at baseline in water from household storage containers were significantly lower (mean difference of free chlorine $=-0.23,95 \% \mathrm{Cl}-1.64,0.17$ ) than from post-treated water in household storage containers. However, mean chlorine levels in post-treated household storage container water samples (taken within 24 hours of treatment) were significantly lower [(mean difference of free chlorine $=-0.71(p<0.005)]$ than the water collected directly from the Zimba. Concentration of chlorine was significantly lower in baseline water samples from household storage containers (mean difference of free chlorine $=-1.25 \% \mathrm{Cl}$ $-1.65,-0.889)$ and from post-treated water from household storage containers (mean difference of free chlorine $=-1.01(95 \% \mathrm{Cl}$ $-1.362,-0.84)$ compared to the project provided safe storage containers. The average concentration of free residual chlorine in post-treated Zimba water samples was $2.11 \mathrm{mg} / \mathrm{L}$, post-treated household stored water samples in their vessel was $0.39 \mathrm{mg} / \mathrm{L}$, and post-treated household stored water samples in project provided safe storage containers were $1.4 \mathrm{mg} / \mathrm{L}$ (Table 2).

All post-treated Zimba water samples (100\%) and project provided safe storage containers were free from E. coli. More than $40 \%$ of post-treated water samples from household storage containers were contaminated with at least one E. coli. $\log _{10} \operatorname{mean} E$. coli concentrations were significantly lower in the project provided safe storage containers $\left[\left(\log _{10}\right.\right.$ mean difference $=0.92 \mathrm{MPN}$, $95 \% \mathrm{Cl} 0.59,1.14)]$ compared to baseline and at post-treated household storage containers $\left[\left(\log _{10}\right.\right.$ mean difference $=0.57 \mathrm{MPN}$, 
$95 \% \mathrm{Cl} 0.32,0.83)]$. We did not find a significant difference in $E$. coliconcentration between baseline and post-treated in water samples from household storage containers [ $\left(\log _{10}\right.$ mean difference $\left.\left.=0.34 \mathrm{MPN}, 95 \% \mathrm{Cl}-0.03,-0.73\right)\right]$ (Table 2).

After treatment, household stored water samples with free residual chlorine within the $0.2-2 \mathrm{mg} / \mathrm{L}$ range had less microbial contamination ( $\log _{10}$-mean E. coli $\left.=-0.10 \mathrm{MPN} / 100 \mathrm{~mL}\right)$ compared to samples with chlorine level $<0.2 \mathrm{mg} / \mathrm{L}\left(\log _{10}\right.$-mean $E$. coli $=037$ MPN/100 mL; log-mean difference $=0.43, p<0.005$ ). Only $3 \%$ of samples were above the detection limit, so this did not affect $E$. coli concentration analysis.

\section{Acceptability and perception of chlorine-treated water}

Within seven days of Zimba installation, 13 surveyed households (65\%) complained about the smell of chlorine/medicine in Zimba-treated water. Only $25 \%$ of households were satisfied with the Zimba chlorination system. The main reasons for dissatisfaction were increased height of the tubewell (75\%); the long time needed to pump $10 \mathrm{~L}$ of water $(85 \%)$, the smell of chlorine/medicine (70\%), and the Zimba was not suitable for collecting a small quantity of water $(90 \%)$. Ten percent of households reported hair loss after bathing in Zimba water (Table 3).

After 4 weeks of the Zimba installation, five households (20\%) reported that they did not collect water from the Zimba tubewell because they could not tolerate the treated water's medicinal smell. One household reported that they used to collect Zimba water occasionally. The rest of the 14 intervention households (70\%) collected Zimba water regularly (Table 3). After four weeks of intervention, acceptability of the Zimba chlorinator and/or chlorine smell/taste increased compared to immediately after installation. Only $25 \%$ of households complained about the chlorine/medicinal smell in the water, and $80 \%$ of households were satisfied with the Zimba chlorinator. Qualitative in-depth interviews suggested that most households (7 out of 10) noticed a strong smell of chlorine at the initial stage after Zimba installation, but they became habituated to the smell after a few weeks. Only $25 \%$ of households complained about the increased height of the tubewell, $15 \%$ about the time required to pump $10 \mathrm{~L}$ water, and $20 \%$ about the smell of chlorine/medicine. A greater number of households (75\%) expressed that Zimba was not suitable for collecting a small water quantity and $25 \%$ of households still complained about hair loss after bathing in Zimba water. One household mentioned the height of the tubewell after Zimba's installation made it difficult to pump water. After four weeks of intervention, most of the respondents $(80 \%)$ found the taste/smell of chlorinated water acceptable. They additionally overcame the difficulties faced using the Zimba except for collecting small amounts of water (Table 3 ).

During the in-depth interviews $(n=10)$, all the interviewees clearly understood the Zimba device's function. They mentioned that Zimba makes the water potable by killing germs. However, all households mentioned that they thought Zimba water was safer for themselves and their children than untreated water. Some households (3 out of 10) mentioned that they had to wait in a long line to collect Zimba water. All the households mentioned that if given proper training on the maintenance and refill of Zimba machines, they would be able to do it themselves; however, they would need technical assistance to repair the machine if broken or nonfunctioning. Only two households mentioned that they would pay a monthly fee to use Zimba. All the other households mentioned that they would have to go back to having untreated, unsafe water if they had to pay for water treatment (Table 3 ).

\section{Interaction between iron concentration and free residual chlorine}

The free and total residual chlorine decay rate was higher in tubewell water with high iron content. The average iron concentration in water from tubewell ID-13 was $6.5 \mathrm{mg} / \mathrm{L}$, and immediately after treatment with $2.85 \%$ diluted $\mathrm{NaOCl}$ solution, we achieved 1.5 $\mathrm{mg} / \mathrm{L}$ free residual chlorine. The mean iron concentration in household storage containers near tubewell ID- $13 \mathrm{was} 3.9 \mathrm{mg} / \mathrm{L}$, we achieved $0.3 \mathrm{mg} / \mathrm{L}$ free residual chlorine within 24 hours of water collection. The mean concentration of iron in tubewell ID-5 was $1.5 \mathrm{mg} / \mathrm{L}$, and immediately after treatment with $2.25 \%$ diluted $\mathrm{NaOCl}$ solution, we achieved $2.5 \mathrm{mg} / \mathrm{L}$ free residual chlorine. The mean iron concentration in water from household storage containers near t tubewell ID- 5 was $0.7 \mathrm{mg} / \mathrm{L}$, we achieved $0.4 \mathrm{mg} / \mathrm{L}$ free residual chlorine within 24 hours of water collection. There was no difference in free and total residual concentration in household stored water when using a different dilution of $\mathrm{NaOCl}$ to treat water (Table 4). For both tubewells, all water samples immediately after treatment had $>0.2 \mathrm{mg} / \mathrm{L}$ free residual chlorine. However, more than $75 \%$ of stored post-treated water from household storage containers had free residual below $0.20 \mathrm{mg} / \mathrm{L}$ during follow-up visits (Table 3 ). The concentration of free 
residual chlorine was consistently higher during all follow-up visits in the project provided safe storage containers compared to post-treated household storage containers (Figure 1).

\section{Discussion}

This was the first-of-its-kind attempt to treat underground shallow tubewell water using an automated chlorinator in a humanitarian setting, albeit on a very small scale. Our results suggested that the concentration of free and total residual chlorine in water samples collected directly from the Zimba and from the project provided safe storage containers was consistently observed to be within and above the WHO recommended range. We also found that the project provided safe storage containers had significantly higher free and total residual chlorine concentration than baseline and post-treated water from household storage containers.

There are several potential reasons for residual chlorine failure in post-treated water from household storage containers. This might be explained by households collecting drinking water from untreated sources. Our results show that after four weeks of intervention, five households (20\%) reported that they did not collect water from the Zimba tubewell because they could not tolerate the treated water's medicinal smell. One household reported that they previously collected Zimba water but currently stopped using because of increased height of the tubewell. Some regular Zimba users (3 out of 10) also mentioned that they had to wait in a long line to collect Zimba water. Alternatively, the two tubewells had iron concentration (mean iron concentration in tubewell ID 5: $1.5 \mathrm{mg} / \mathrm{L}$ and tubewell ID $3: 6.5 \mathrm{mg} / \mathrm{L}$ ), that likely exerted substantial chlorine demand. Our result suggested that if groundwater concentration of iron exceeds $7.0 \mathrm{mg} / \mathrm{L}$, treatment dose would need to be at high concentration (3.5\%) to achieve WHO recommended free residual chlorine in the treated water. We found that the average free chlorine residual from direct Zimba water samples was more than $2.10 \mathrm{mg} / \mathrm{L}$ immediately post-treatment, which decreased to $0.39 \mathrm{mg} / \mathrm{L}$ in post-treated household storage containers and $1.4 \mathrm{mg} / \mathrm{L}$ in post-treated project provided safe storage containers within 24 hours of treatment. This result is consistent with a recent study conducted in rural Bangladesh on groundwater chlorination that suggested groundwater with iron (>3 mg/L) may have low-level or no residual after chlorination (36). Our results suggested that different doses of chlorine ( $\mathrm{NaOCl}$ or $\mathrm{NaDCC}$ ) are required to treat groundwater in the FDMN-camps. Our study recommends that if water source concentration of iron exceeds $7.0 \mathrm{mg} / \mathrm{L}$ chlorination should be avoided (37), or before chlorination, the water should be treated with Potassium permanganate $\left(\mathrm{KMnO}_{4}\right)$ and lime to remove iron (41). Future studies should explore the options for treating groundwater with a high concentration of iron concentration in low-resource setting.

We found that the project provided safe storage containers had significantly lower $E$. coli concentration, higher residual total and free chlorine than baseline and post-treated water from household storage containers. Households may have unsafely managed water stored in vessels; at baseline we observed that $70 \%$ of the household storage containers were not appropriately covered. Recently, it was reported that water sources in FDMN-camps were unevenly distributed. Many people walk long distances through densely inhabited camps after collecting water $(30,31)$, providing opportunity for contamination due to unsafe handling during transport. Furthermore, household storage containers in humanitarian settings often had observed faecal contamination likely due to insufficient regular cleaning (32). Project provided safe storage containers had a small opening and were likely accessed less frequently, providing fewer opportunities for contamination and chlorine dissipation. This signifies that it is vital for successful water chlorination projects in humanitarian settings to ensure that users collect water from treated sources in safe storage containers for recommended periods $(33,34)$. Safe handling from collection to pouring into a glass for drinking is crucial for a successful water treatment program (35).

Our qualitative results found that most households (7 out of 10) detected a strong chlorine smell at the initial stage of Zimba installation, but became habituated to the smell after four weeks of intervention. After four weeks of intervention the Zimba device's acceptability $(70 \%$ collected Zimba water regularly and $80 \%$ of households were satisfied with the Zimba chlorinator performance) increased significantly compared to immediately (seven days) after Zimba installation. Unlike the Dhaka Zimba trial, we addressed the problems related to increased tubewell height by constructing a raised footstep (Figure S3), the smell/taste of chlorine by adjusting the chlorine dosage and periodic behavior change communication messages after seven days of Zimba installation. Despite Zimba acceptability, $75 \%$ of households reported that Zimba was not suitable for collecting a small water quantity for example the volume needed to for anal cleansing after defecation. The Zimba attached to the tubewell required 
pumping 10-L to treat each batch of water which was time-consuming when requiring only a small amount of water. An alternative water reservoir located near the latrine may overcome this limitation.

The Zimba is less expensive than a centralized piped water chlorination system. It does not require household level distribution of chlorine products [i.e., Aquatabs, Halotabs (Halazone $7.5 \mathrm{mg}$ tablet, Sonear Laboratories Ltd., Motijhil, Dhaka)] or similar.), which can be expensive and not always feasible in humanitarian settings. Zimba can be constructed in the local markets and does not need a high-tech manufacturer. The Zimba device is attached/locked to the tubewell and automatically treats water without the active participation of users (22). Since household members cannot choose whether to chlorinate, they may be more likely to adjust to the consistently chlorinated water's smell and taste. The concentrations of $\mathrm{NaOCl}$ can be adjusted depending on the water iron concentration with Zimba. In our study, all Zimbas were installed by NGO handpump mechanics, and the NGO field staff was trained to dilute $\mathrm{NaOCl}$ and refill the Zimba. In our previous Zimba trial in Dhaka, we followed similar approaches and engaged community members for Zimba installation, chlorine refills, and maintenance (22).

In both the Dhaka Zimba trial (22) and during the current trial in FDMN-camps, two Zimbas were removed immediately after installation. In the Dhaka trial, one Zimba was withdrawn because long lines developed, as it took a long time to pump the water. With the other Zimba, the amount of space occupied by the device hindered regular cleaning. In our current study, we removed one Zimba due to a very high $(7 \mathrm{mg} / \mathrm{L})$ concentration of iron in the source groundwater. The other became too tight to pump due to an increase in the height of the handpump barrel after installation. This suggest that a successful chlorination project that uses automated chlorinators like Zimba must study neighborhood contexts, number of users per water source, type/source of water supply (i.e., municipal piped, groundwater), and geographical variation of water chemistry (e.g. iron, TDS, turbidity, chlorine). This Zimba was innovative, effective, and easy-to-install at the source, does not require any electricity, no expertise required for maintenance, and local NGO workers/volunteers can install and refill the dispenser along with their regular activities. Finally, our study proved that the users become quickly accustomed to the chlorine taste and smell, requiring less behavior change communication than other chlorine products (i.e., NaDCC). Future water treatment studies with automated chlorinators should focus on characteristics that impact long-term interventions with more comprehensive geographically distributed water sources.

More than $41 \%$ of drinking water in our post-treated household storage containers were found contaminated with at least one MPN E. coli/100 mL. Possible explanations of E. coli in treated water include collecting water from other tubewells, low or no chlorine residual from Zimba due to inconsistencies in dosing, or utilization of residual chlorine due to consumption of free chlorine due to interaction between iron and $\mathrm{NaOCl}$ and/or due to unsafe handling of stored water that leads to recontamination (38). Recent studies from rural Bangladesh also reported an inverse relationship between free residual chlorine and iron concentration in tubewell water (36) which confirms findings from several studies that the high-water iron content reduces the microbial effectiveness of chlorination $(41,42)$.

Despite the success of the trial, this study had some important limitations. No other comparable water treatment technologies were available at the time of this study in FDMN-camps, to compare the Zimba chlorinator's effectiveness. Further research should compare the dosing and microbial efficiency of Zimba with inline centralized water treatment technologies (22). Tubewells that were included in this study were not contaminated with faecal bacteria. Results might differ if the source water (tubewell) is contaminated, as reported for numerous camps (9). Recent POU water treatment trials using automated chlorinators in urban Dhaka suggested that despite the high faecal contamination in source water, household faecal contamination reduced significantly in the stored water after chlorination $(21,22)$. Considering the high risk of waterborne disease outbreaks in humanitarian settings, a water chlorination programme should still be considered when there is no apparent contamination in the source water, as post-treatment contamination is common in this setting. The study participants were enrolled from only two FDMN-camps in Cox's Bazar; thus, the acceptability, adoption, $\mathrm{NaOCl}$ dosing, and treatment efficacy may not be similar to the host communities and other camps at Cox's Bazar. We assessed the acceptability of Zimba and chlorine smell/taste only for four weeks. It is not easy to measure the acceptability and adoption within a short period. Adoption of new technology requires longterm promotion to change behavior (21). Studies suggested that aversion to chlorinated water's taste or smell can limit the use of chlorine products $(\mathrm{NaOCl}$ or $\mathrm{NaDCC})(18,22)$. Adopting a new automated chlorinator depends on the users' successful performance and initial acceptance. In contrast, the adoption of $\mathrm{NaOCl}$ relies on successful sustained behavior change at the household level (21). 
We measured the iron concentration of tubewells only during the monsoon season. However, seasonal variation in iron concentration has been observed in shallow groundwater aquifers in Bangladesh (39). Although we only tested the iron and turbidity of tubewell and household stored water, other groundwater inorganic cations similarly interact with chlorine. Research has demonstrated positive correlations between groundwater iron concentration and other chemicals such as arsenic, manganese and heavy metals; our iron measurement could be indicative of the presence of a range of chemicals that exert chlorine demand $(37,40)$. Finally, we only tested Zimba at two water points in FDMN-camps. Elsewhere in FDMN-camps, water points could have different physiochemical and/or mechanical differences, altering Zimba's performance. Future studies with automated chlorinators should focus on large-scale trials with long-term interventions to adopt with Zimba device and chlorine taste/smell.

\section{Conclusion}

Our research findings have important public health implications for the dosing and promotion of an automated chlorinator for the disinfection of groundwater in humanitarian settings. Chlorination is widely used for drinking-water treatment in emergency settings, but due to the lack of appropriate technology chlorination program often fails. Existing water treatment options are expensive and often require sustainable behavior changes for adoption. Zimba is easy to install and requires no expert workforce. People from existing FDMN programme staff can refill the required $\mathrm{NaOCl}$ and clean Zimba, improving the microbial water quality. Continuous supply of precise and automated chlorination below the taste and/or smell recognition level likely increases acceptability and use of chlorine-treated water (20). We found that the automated chlorination approach using Zimba to treat underground water with different iron levels could be an effective strategy to treat wide ranges of underground water to reduce enteric disease in humanitarian settings. Further water chlorination research is essential to investigate the causes of concentration of residual chlorine in stored water at households for effective water treatment and impact microbial water contamination and health. The results from this study will provide a guideline to the humanitarian WASH sectors to appropriately chlorinate source water, which ultimately improves water quality in the FDMN-camp.

\section{Declarations}

\section{Availability of data and materials}

The datasets, codebook used and/or analyzed during the present study are available from the corresponding author on reasonable request.

\section{Acknowledgments}

We thank the study respondents for participating in the study. We acknowledge coordinal support from Action Against Hunger staff Alex Loriaman to select tubewells and support with staff for Zimba installation. The authors gratefully acknowledge Mehjabin Tishan Mahfuz for a thoughtful review of the manuscript and Anika Tasneem for data management. Suprio Das, the inventor of Zimba, contributed Figure S1 in this manuscript. We would also like to thank Suprio Das and Barid Tarafdar for manufacturing and installing Zimba devices evaluated in this study. We acknowledge the contributions of icddr,b Dhaka field team: Raju Ahmed, Badal Hawlader, Alam Mia, and all data collectors. icddr,b is also grateful to the Governments of Bangladesh, Canada, Sweden, and the UK for providing core/unrestricted support.

\section{Funding}

Funding support was provided by the Action Against Hunger (agreement ref\# F7F/icddr,b/1/22072018). Co-authors Md. Kawsar Alome and Maksudul Amin are employed by the funding agency and participated in the study design and review of the manuscript.

\section{Author information}

\section{Affiliations}

1. Environmental Interventions Unit, Infectious Diseases Division, icddr,b, Dhaka 1212, Bangladesh 
Nuhu Amin, Mahbubur Rahman, Mahbub-Ul Alam, Abul Kasham Shoab, Tarique Mohammad Nurul Huda, and Leanne Unicomb

\section{Action Against Hunger, Dhaka-1212, Bangladesh}

Md. Kawsar Alome and Maksudul Amin

\section{Authors' contributions}

NA, MR, MUA, TMNH, and LU designed the study. MUA, MKA, and MA conducted the data collection, and MKA and MA assisted with field operations. NA and AKS conducted data analysis. NA wrote this paper with substantial input from all other authors. All authors have reviewed and approved the submitted manuscript. The study findings and conclusions in this manuscript are those of the authors and do not necessarily represent the Action Against Hunger's official position.

\section{Corresponding author}

Correspondence to Nuhu Amin

\section{Declaration:}

\section{Ethics approval and consent to participate}

The study protocol was reviewed and approved by the Institutional Scientific and Ethical Review Committees at the International Centre for Diarrhoeal Disease Research, Bangladesh (icddr,b) (protocol number \# PR-18029) and Office of the Refugee Relief and Repatriation Commission (RRRC), Cox's Bazar.

\section{Consent for publication}

All co-authors provided written consent (E. mail) and agreed to be a co-author in this paper. All co-authors also provided written (E. mail) consent for publication.

\section{Competing interests}

The authors declare that they have no competing interests.

\section{References}

1. WHO. Drinking-water. Retrieved from https://www.who.int/news-room/fact-sheets/detail/drinking-water. 2018.

2. Ramesh A, Blanchet K, Ensink JHJ, Roberts B. Evidence on the Effectiveness of Water, Sanitation, and Hygiene (WASH) Interventions on Health Outcomes in Humanitarian Crises: A Systematic Review. PloS one. 2015;10(9):e0124688-e.

3. Shannon K, Hast M, Azman AS, Legros D, McKay H, Lessler J. Cholera prevention and control in refugee settings: Successes and continued challenges. PLoS Negl Trop Dis. 2019;13(6):e0007347-e.

4. Haar RJ, Wang K, Venters H, Salonen S, Patel R, Nelson T, et al. Documentation of human rights abuses among Rohingya refugees from Myanmar. Confl Health. 2019;13(1):42.

5. Messner N, Woods A, Petty A, Parmar PK, Leigh J, Thomas E, et al. Qualitative evidence of crimes against humanity: the August 2017 attacks on the Rohingya in northern Rakhine State, Myanmar. Confl Health. 2019;13(1):41.

6. UNHCR. Fighting water scarcity in Cox's Bazar refugee camps. Available at https://www.unhcr.org/news/latest/2019/1/5c2fc16a4/fighting-water-scarcity-coxs-bazar-refugee-camps.html and accessed on August 29, 2020. 2019.

7. Hasan MK, Shahriar A, Jim KU. Water pollution in Bangladesh and its impact on public health. Heliyon. 2019;5(8):e02145-e.

8. van Geen A, Ahmed KM, Akita Y, Alam MJ, Culligan PJ, Emch M, et al. Fecal contamination of shallow tubewells in Bangladesh inversely related to arsenic. Environmental science \& technology. 2011;45(4):1199-205.

9. Mahmud ZH, Kabir MH, Ali S, Moniruzzaman M, Imran KM, Nafiz TN, et al. Extended-Spectrum Beta-Lactamase-Producing Escherichia coli in Drinking Water Samples From a Forcibly Displaced, Densely Populated Community Setting in Bangladesh. 
Frontiers in Public Health. 2020;8(228).

10. icddr b, unicef. Fact Sheet -8: A Bacteriological Water Quality Issue: Rohingya "Forcefully Displaced Myanmar Citizen" Camp in Cox's Bazar, Bangladesh. Available at https://reliefweb.int/sites/reliefweb.int/files/resources/fact_sheet8_upto_6th_august-2018_final.pdf and accessed on April 15, 2019. 2018.

11. Lantagne D, Clasen T. Effective use of household water treatment and safe storage in response to the 2010 Haiti earthquake. The American journal of tropical medicine and hygiene. 2013;89(3):426-33.

12. Lantagne DS, Blount BC, Cardinali F, Quick R. Disinfection by-product formation and mitigation strategies in point-of-use chlorination of turbid and non-turbid waters in western Kenya. Journal of water and health. 2008;6(1):67-82.

13. D'Mello-Guyett L, Yates T, Bastable A, Dahab M, Deola C, Dorea C, et al. Setting priorities for humanitarian water, sanitation and hygiene research: a meeting report. Confl Health. 2018;12:22.

14. Loo S-L, Fane AG, Krantz WB, Lim T-T. Emergency water supply: A review of potential technologies and selection criteria. Water research. 2012;46(10):3125-51.

15. Alam; M-U, Unicomb; L, Ahasan; SMM, Amin; N, Biswas; D, Ferdous; S, et al. Barriers and Enabling Factors for Central and Household Level Water Treatment in a Refugee Setting: A Mixed-Method Study among Rohingyas in Cox's Bazar, Bangladesh. Water. 2020;00(00):00.

16. Clasen T, Edmondson P. Sodium dichloroisocyanurate (NaDCC) tablets as an alternative to sodium hypochlorite for the routine treatment of drinking water at the household level. International journal of hygiene and environmental health. 2006;209(2):173-81.

17. Kremer M, Miguel E, C N. Sustainability of long-term take-up at point-of-collection chlorine dispensers provided free of charge in rural Western Kenya. Proceedings of the Water Environment Federation. 2011;2011:249-50.

18. Crider Y, Sultana S, Unicomb L, Davis J, Luby SP, Pickering AJ. Can you taste it? Taste detection and acceptability thresholds for chlorine residual in drinking water in Dhaka, Bangladesh. Science of The Total Environment. 2018;613-614:840-6.

19. Yeasmin F, Sultana F, Unicomb L, Nizame FA, Rahman M, Kabir H, et al. Piloting a Shared Source Water Treatment Intervention among Elementary Schools in Bangladesh. The American journal of tropical medicine and hygiene. 2019;101(5):984-93.

20. Pickering AJ, Crider Y, Sultana S, Swarthout J, Goddard FGB, Anjerul Islam S, et al. Effect of in-line drinking water chlorination at the point of collection on child diarrhoea in urban Bangladesh: a double-blind, cluster-randomised controlled trial. The Lancet Global Health. 2019;7(9):e1247-e56.

21. Pickering AJ, Crider Y, Amin N, Bauza V, Unicomb L, Davis J, et al. Differences in Field Effectiveness and Adoption between a Novel Automated Chlorination System and Household Manual Chlorination of Drinking Water in Dhaka, Bangladesh: A Randomized Controlled Trial. PloS one. 2015;10(3):e0118397.

22. Amin N, Crider YS, Unicomb L, Das KK, Gope PS, Mahmud ZH, et al. Field trial of an automated batch chlorinator system at shared water points in an urban community of Dhaka, Bangladesh. Journal of Water Sanitation and Hygiene for Development. 2016;6(1):32-41.

23. Lippy EC. Chlorination to Prevent and Control Waterborne Diseases. Journal - AWWA. 1986;78(1):49-52.

24. IDEXX. IDEXX Summary: evaluation of colilert and interolert defined substrate Methodology for wastewater application. Available athttp://www.idexx.co.uk/pdf/en_gb/water/64194006K.pdf and accessed on February 1, 2018. 2002.

25. Amin; N, Liu; P, Foster; T, Rahman; M, Miah; MR, Ahmed; GB, et al. Pathogen flows from on-site sanitation systems in lowincome urban neighborhoods, Dhaka: A quantitative environmental assessment. Int J Hyg Environ Health 2020;00(00):000.

26. Amin N, Pickering AJ, Ram PK, Unicomb L, Najnin N, Homaira N, et al. Microbiological evaluation of the efficacy of soapy water to clean hands: a randomized, non-inferiority field trial. The American journal of tropical medicine and hygiene. 2014;91(2):415-23.

27. Amin N, Rahman M, Raj S, Ali S, Green J, Das S, et al. Quantitative assessment of fecal contamination in multiple environmental sample types in urban communities in Dhaka, Bangladesh using SaniPath microbial approach. bioRxiv. 2019:723528.

28. WHO. Total dissolved solids in Drinking-water: Background document for development of WHO Guidelines for Drinking-water Quality. Available at https://www.who.int/water_sanitation_health/dwq/chemicals/tds.pdf and accessed on September 19, 
2019. 2003.

29. WHO. Guidelines for drinking-water quality: Surveillance and control of community supplies. Available at https://www.who.int/water_sanitation_health/dwq/gdwqvol32ed.pdf and accessed on September 19, 2019. 1997.

30. Alam M-U, Unicomb L, Ahasan S, Amin N, Biswas D, Ferdous S, et al. Barriers and Enabling Factors for Central and Household Level Water Treatment in a Refugee Setting: A Mixed-Method Study among Rohingyas in Cox's Bazar, Bangladesh. Water. 2020;12(11):3149.

31. Akhter M, Uddin SMN, Rafa N, Hridi SM, Staddon C, Powell W. Drinking Water Security Challenges in Rohingya Refugee Camps of Cox's Bazar, Bangladesh. Sustainability. 2020;12(18):7325.

32. Steele A, Clarke B, Watkins 0 . Impact of jerry can disinfection in a camp environment - experiences in an IDP camp in Northern Uganda. Journal of water and health. 2008;6(4):559-64.

33. WHO. Guidelines for drinking-water quality- Second Edition: Volume 3 Surveillance and control of community supplies. 1997.

34. Ercumen A, Naser AM, Unicomb L, Arnold BF, Colford Jr JM, Luby SP. Effects of Source- versus Household Contamination of Tubewell Water on Child Diarrhea in Rural Bangladesh: A Randomized Controlled Trial. PloS one. 2015;10(3):e0121907.

35. Clasen TF, Bastable A. Faecal contamination of drinking water during collection and household storage: the need to extend protection to the point of use. Journal of water and health. 2003;1(3):109-15.

36. Naser AM, Higgins EM, Arman S, Ercumen A, Ashraf S, Das KK, et al. Effect of Groundwater Iron on Residual Chlorine in Water Treated with Sodium Dichloroisocyanurate Tablets in Rural Bangladesh. The American journal of tropical medicine and hygiene. 2018;98(4):977-83.

37. Naser AM, Higgins EM, Arman S, Ercumen A, Ashraf S, Das KK, et al. Effect of Groundwater Iron on Residual Chlorine in Water Treated with Sodium Dichloroisocyanurate Tablets in Rural Bangladesh. The American journal of tropical medicine and hygiene. 2018;98(4):977-83.

38. Quick RE, Venczel LV, Gonzalez O, Mintz ED, Highsmith AK, Espada A, et al. Narrow-mouthed water storage vessels and in situ chlorination in a Bolivian community: a simple method to improve drinking water quality. American journal of tropical medicine and hygiene. 1996;54(5):511-6.

39. Dhar RK, Zheng Y, Stute M, van Geen A, Cheng Z, Shanewaz M, et al. Temporal variability of groundwater chemistry in shallow and deep aquifers of Araihazar, Bangladesh. J Contam Hydrol. 2008;99(1-4):97-111.

40. Ayotte JD, Nielsen MG, Robinson Jr GR, Moore RB. Relation of arsenic, iron, and manganese in ground water to aquifer type, bedrock lithogeochemistry, and land use in the New England coastal basins. Report. 1999. Report No.: 99-4162.

41. Khadse, G.K., Patni, P.M. \& Labhasetwar, P.K. Removal of iron and manganese from drinking water supply. Sustain. Water Resour. Manag. 2015; 1, 157-165.

42. Merrill R, Labrique A, Shamim A, Schulze K, Christian P, West K, 2010. Elevated and variable groundwater iron in rural northwestern Bangladesh. J Water Health 8: 818-825.

\section{Tables}

Table 1: Demographic characteristics, water collection, storage practice, and drinking water satisfaction level at baseline, in FDMNcamp, Cox's Bazar, 2018 


\begin{tabular}{|c|c|}
\hline \multirow[t]{3}{*}{ Characteristics } & Households \\
\hline & $N=20$ \\
\hline & $\mathrm{n}(\%)$ \\
\hline \multicolumn{2}{|l|}{ Demographics } \\
\hline Mean age (years) of the respondents (range) & $37(18-65)$ \\
\hline \multicolumn{2}{|l|}{ Education of the respondents } \\
\hline No formal schooling & $13(65)$ \\
\hline Up to 5 th grade & $4(20)$ \\
\hline Secondary School & $3(15)$ \\
\hline \multicolumn{2}{|l|}{ Education of the household head } \\
\hline No formal schooling & $7(35)$ \\
\hline Up to 5 th grade & $5(25)$ \\
\hline Secondary School & $6(30)$ \\
\hline College/University & $1(5)$ \\
\hline Mean number of children/household <5 (SD) & $2(1.3)$ \\
\hline Mean number of household members (SD) & $6(3.2)$ \\
\hline \multicolumn{2}{|l|}{ Occupation of the household head } \\
\hline Fixed/contractual job & $7(35)$ \\
\hline Self-employed or own business & $5(25)$ \\
\hline Day labor & $6(30)$ \\
\hline Unemployed & $2(10)$ \\
\hline \multicolumn{2}{|l|}{ Household income } \\
\hline No income & $2(10)$ \\
\hline$=<5,000$ BDT $(=<60$ USD $)$ & $9(45)$ \\
\hline$>5,000$ BDT $-<10,000$ BDT $(>60-<115$ USD $)$ & $6(30)$ \\
\hline 10,000 BDT or above (=>115 USD) & $3(15)$ \\
\hline Average household income (BDT) (range) & $5,705(0-15,000)$ \\
\hline \multicolumn{2}{|l|}{ Water collection and storage practice } \\
\hline \multicolumn{2}{|l|}{ Vessels used for drinking water collection } \\
\hline Kolshi (traditional metal pot, 5L and 10L) & $12(60)$ \\
\hline Bucket (10L and 15L) & $4(20)$ \\
\hline Plastic jug (2-3L) & $4(20)$ \\
\hline \multicolumn{2}{|l|}{ observed Water storage covering } \\
\hline Fully covered with solid lid & $6(30)$ \\
\hline Partially covered/ covered with non-solid lid (paper/perforated lid) & $12(60)$ \\
\hline Not covered & $2(10)$ \\
\hline
\end{tabular}

Page 15/21 


\begin{tabular}{|ll|}
\hline Characteristics & Households \\
& $\mathrm{N}=20$ \\
$\mathrm{n}(\%)$ & \\
\hline Level of satisfaction ${ }^{\dagger}$ with existing drinking water & \\
\hline Generally satisfied with water supply (amount available plus quality) & $19(95)$ \\
\hline Water available at sources at a predictable time (Yes) & $20(100)$ \\
\hline Water available 24 hours & $20(100)$ \\
\hline Described water taste as good & $19(95)$ \\
\hline Described water taste as not good (e.g. soil, dirt, chemical smell) & $1(5)$ \\
\hline
\end{tabular}

*1 US\$ = 85 taka

${ }^{\dagger}$ Perceived satisfaction reported by the respondents 
Table 2: Water chlorine residual and iron concentration among households during weekly follow up household visits, in FDMNcamp, Cox's Bazar, 2018

\begin{tabular}{|c|c|c|c|c|c|c|c|c|}
\hline & \multirow{2}{*}{$\begin{array}{l}\begin{array}{l}\text { Source } \\
\text { water }\end{array} \\
\text { Tubewell } \\
\text { n (\%) }\end{array}$} & \multirow{2}{*}{$\begin{array}{l}\begin{array}{l}\text { Baseline } \\
\text { stored } \\
\text { water }\end{array} \\
\text { Household } \\
\text { own } \\
\text { vessel } \\
\text { n (\%) }\end{array}$} & \multirow{2}{*}{$\begin{array}{l}\text { Immediately } \\
\text { after } \\
\text { treatment } \\
\text { Zimba } \\
\text { water } \\
\text { n (\%) }\end{array}$} & \multicolumn{2}{|c|}{$\begin{array}{l}\text { Post-treated follow-up } \\
\text { visits: stored water }\end{array}$} & \multicolumn{3}{|c|}{$\begin{array}{l}\text { Mean differences between baseline } \\
\text { vs. post-treated follow-up visits }\end{array}$} \\
\hline & & & & $\begin{array}{l}\text { Household } \\
\text { own } \\
\text { vessel } \\
\text { n (\%) }\end{array}$ & $\begin{array}{l}\text { Project } \\
\text { provided } \\
\text { safe } \\
\text { storage } \\
\text { containers } \\
\text { n (\%) }\end{array}$ & $\begin{array}{l}\text { Baseline } \\
\text { household } \\
\text { stored } \\
\text { water } \\
\text { minus } \\
\text { post- } \\
\text { treated } \\
\text { household } \\
\text { own } \\
\text { vessel } \\
(95 \% \mathrm{Cl})\end{array}$ & $\begin{array}{l}\text { Baseline } \\
\text { household } \\
\text { stored } \\
\text { water } \\
\text { minus } \\
\text { project } \\
\text { provided } \\
\text { safe } \\
\text { storage } \\
(95 \% \mathrm{Cl})\end{array}$ & $\begin{array}{l}\text { Project } \\
\text { provided } \\
\text { safe } \\
\text { storage } \\
\text { container } \\
\text { minus } \\
\text { post- } \\
\text { treated } \\
\text { household } \\
\text { own } \\
\text { vessel } \\
\text { (95\% Cl) }\end{array}$ \\
\hline $\begin{array}{l}\text { Turbidity } \\
\text { (NTU) }\end{array}$ & $\mathrm{N}=2$ & $\mathrm{~N}=20$ & $\mathrm{~N}=2$ & $\mathrm{~N}=84$ & $N=15$ & & & \\
\hline$<5$ & $2 *(100)$ & $17(85)$ & $3 *(100)$ & 77 (91.7) & $14(93.7)$ & & & \\
\hline 5 and above & 0 & $3(15)$ & 0 & $7(8.3)$ & $1(6.7)$ & & & \\
\hline Mean (SD) & $\begin{array}{l}2.55 \\
(2.3)\end{array}$ & $2.6(5.7)$ & $2.50(2.2)$ & $1.8(3.2)$ & $2.81(2.7)$ & $\begin{array}{l}0.76 \\
(-1.96 \\
3.48)\end{array}$ & $\begin{array}{l}-0.21 \\
(-3.170 \\
2.749)\end{array}$ & $\begin{array}{l}0.97 \\
(-2.587 \\
0.650)\end{array}$ \\
\hline $\begin{array}{l}\text { Total } \\
\text { Dissolved } \\
\text { Solids (ppm) }\end{array}$ & $\mathrm{N}=2$ & $\mathrm{~N}=\mathbf{2 0}$ & $\mathrm{N}=2$ & $N=133$ & $\mathrm{~N}=22$ & & & \\
\hline $\begin{array}{l}<300 \\
\text { (excellent) }\end{array}$ & $2^{\star}(100)$ & $10(50)$ & $2 *(66.7)$ & $70(52.5)$ & $12(54.6)$ & & & \\
\hline $300-500$ (fair) & 0 & $10(50)$ & $1 *(33.3)$ & $63(47.3)$ & $10(45.5)$ & & & \\
\hline Mean (SD) & $\begin{array}{l}240.3 \\
(119.9)\end{array}$ & $\begin{array}{l}238.0 \\
(92.2)\end{array}$ & $\begin{array}{l}215.3 \\
(115.9)\end{array}$ & $\begin{array}{l}253.1 \\
(88.9)\end{array}$ & $\begin{array}{l}235.4 \\
(90.0)\end{array}$ & $\begin{array}{l}-15.1 \\
(-60.45 \\
30.29)\end{array}$ & $\begin{array}{l}2.69 \\
(-54.265 \\
59.638)\end{array}$ & $\begin{array}{l}17.76 \\
(-24.588, \\
60.117)\end{array}$ \\
\hline $\begin{array}{l}\text { Iron } \\
\text { concentration } \\
\text { (mg/L) }\end{array}$ & $\mathrm{N}=12$ & $\mathrm{~N}=20$ & $\mathrm{~N}=2$ & $\mathrm{~N}=79$ & $\mathrm{~N}=17$ & & & \\
\hline$<1$ & 0 & $9(45)$ & 0 & $35(28.2)$ & $10(58.8)$ & & & \\
\hline $1-<3$ & $6(50.0)$ & $4(20)$ & $1(14.3)$ & $27(34.2)$ & 0 & & & \\
\hline $3-<5$ & 0 & $2(10)$ & 0 & $3(3.8)$ & 0 & & & \\
\hline 5 or above & $6(50.0)$ & $5(25)$ & $6(85.7)$ & $14(17.7)$ & $7(41.2)$ & & & \\
\hline Mean (SD) & $4.0(2.1)$ & $2.2(2.4)$ & $5.8(1.9)$ & $1.9(2.1)$ & $2.8(2.9)$ & $\begin{array}{l}0.59 \\
(-0.846, \\
1.57)\end{array}$ & $\begin{array}{l}-0.54 \\
(-2.34 \\
1.26)\end{array}$ & $\begin{array}{l}-0.91 \\
(-2.45 \\
0.63)\end{array}$ \\
\hline $\begin{array}{l}\text { Free Chlorine } \\
\text { (mg/L) }\end{array}$ & NA & $\mathrm{N}=20$ & $N=323$ & $N=133$ & $\mathrm{~N}=32$ & & & \\
\hline$<0.2$ & NA & $17(85.0)$ & 0 & $101(75.3)$ & $2(6.2)$ & & & \\
\hline $0.2-2$ & NA & $3(15.0)$ & $165(50.0)$ & $24(18.0)$ & $22(68.8)$ & & & \\
\hline$>2$ & NA & 0 & $164(50.0)$ & $8(6.0)$ & $8(25.0)$ & & & \\
\hline
\end{tabular}




\begin{tabular}{|c|c|c|c|c|c|c|c|c|}
\hline $\begin{array}{l}\text { Mean }(\mathrm{mg} / \mathrm{L}) \\
(\mathrm{SD})\end{array}$ & NA & $0.15(0.4)$ & $2.1(1.1)$ & $0.39(0.9)$ & $1.4(0.9)$ & $\begin{array}{l}-0.23 \\
(-0.64 \\
0.17)\end{array}$ & $\begin{array}{l}-1.25 \\
(-1.65 \\
-0.84)\end{array}$ & $\begin{array}{l}-1.01 \\
(-1.36 \\
-0.67)\end{array}$ \\
\hline $\begin{array}{l}\text { Total } \\
\text { Chlorine } \\
\text { (mg/L) }\end{array}$ & NA & $\mathrm{N}=\mathbf{2 0}$ & $\mathrm{N}=72$ & $\mathrm{~N}=133$ & $\mathrm{~N}=32$ & & & \\
\hline$<0.2$ & NA & 17 (85.0) & 0 & 93 (69.9) & $1(3.1)$ & & & \\
\hline $0.2-2$ & NA & 3 (15.0) & $31(43.0)$ & $32(24.0)$ & $22(68.8)$ & & & \\
\hline$>2$ & NA & 0 & $41(57.0)$ & $8(6.0)$ & 9 (28.2) & & & \\
\hline $\begin{array}{l}\text { Mean }(\mathrm{mg} / \mathrm{L}) \\
(\mathrm{SD})\end{array}$ & NA & $0.17(0.4)$ & $2.21(0.95)$ & $0.5(1.1)$ & $1.72(1.0)$ & $\begin{array}{l}-0.16 \\
(-0.68 \\
0.36)\end{array}$ & $\begin{array}{l}-1.39 \\
(-1.88 \\
-1.90)\end{array}$ & $\begin{array}{l}-1.23 \\
(-1.66 \\
-0.80)\end{array}$ \\
\hline $\begin{array}{l}\text { E. coli } \\
\text { MPN/100 ml }\end{array}$ & $\mathrm{N}=2$ & $\mathrm{~N}=\mathbf{2 0}$ & $N=8$ & $N=80$ & $\mathrm{~N}=32$ & & & \\
\hline 0 & 2 (100) & $8(40.0)$ & $8(100)$ & 47 (58.8) & 32 (100) & & & \\
\hline $1-10$ & 0 & $6(30.0)$ & 0 & $22(27.5)$ & 0 & & & \\
\hline$>10$ & 0 & $6(30.0)$ & 0 & 11 (13.7) & 0 & & & \\
\hline $\begin{array}{l}\text { Log-mean } E \text {. } \\
\text { coli } \\
\text { MPN/100 ml } \\
\text { (SD) }\end{array}$ & -0.30 & $0.62(0.9)$ & -0.30 & $\begin{array}{l}0.28 \\
(0.73)\end{array}$ & -0.30 & $\begin{array}{l}0.34 \\
(-0.03 \\
0.73)\end{array}$ & $\begin{array}{l}0.92(0.59 \\
1.24)\end{array}$ & $\begin{array}{l}0.57(0.32, \\
0.83)\end{array}$ \\
\hline
\end{tabular}

*We measured turbidity and total dissolved solids only for two water sources not for all treated water

${ }^{\dagger} 5 \mathrm{~L}$ plastic jerry can

Table 3: Acceptability and satisfaction with water in households at baseline, within 7 days of Zimba installation and at end-line in FDMN-camps, Cox's Bazaar, 2018 


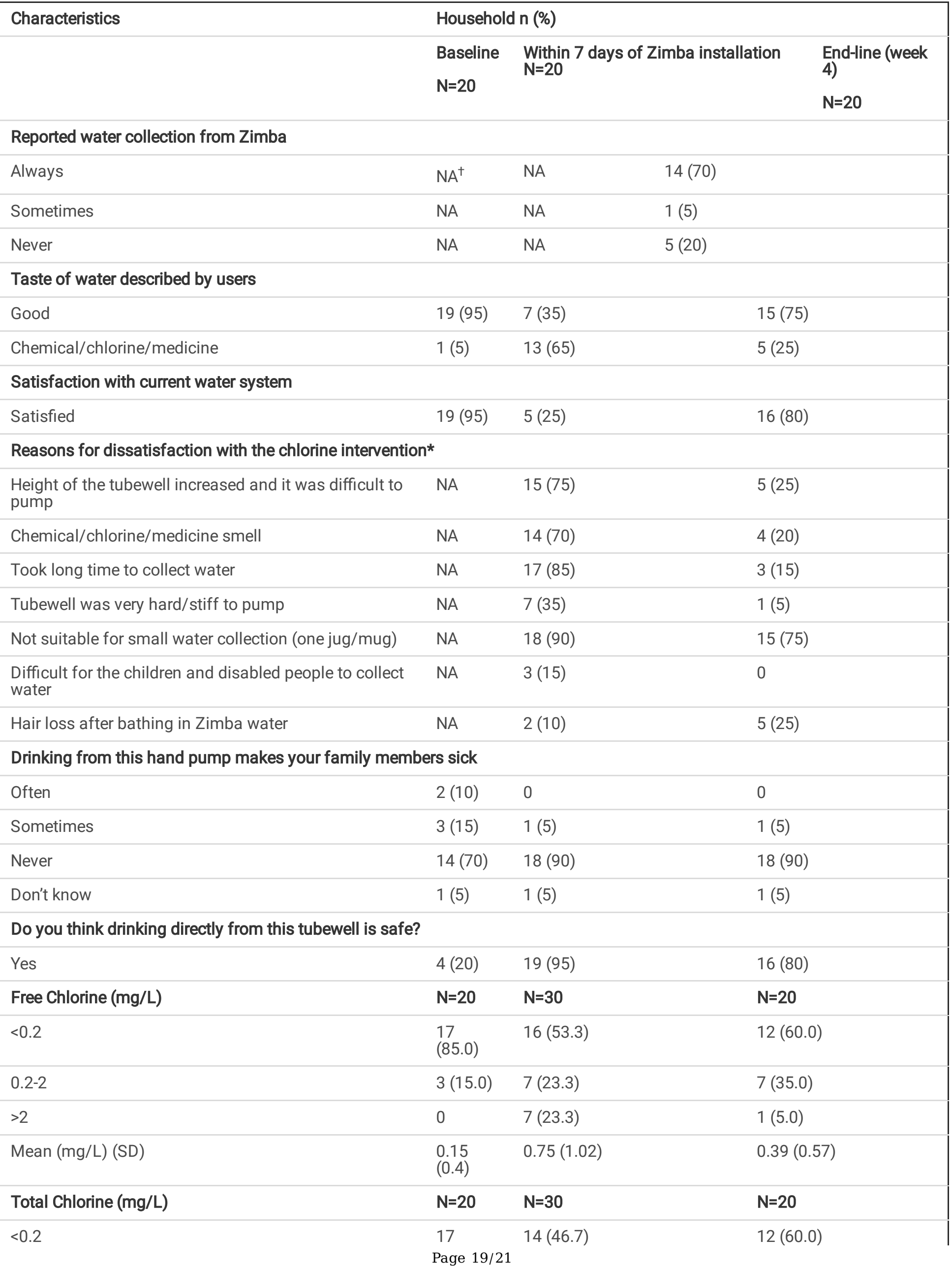


(85.0)

\begin{tabular}{llll}
$0.2-2$ & $3(15.0)$ & $9(30.0)$ & $7(35.0)$ \\
$>2$ & 0 & $7(23.3)$ & $1(5.0)$ \\
\hline Mean (mg/L) (SD) & 0.17 & $0.88(1.12)$ & $0.43(0.58)$ \\
\hline E. coli MPN/100 ml & $(0.4)$ & & $\mathbf{N}=\mathbf{2 0}$ \\
\hline 0 & $\mathbf{N}=\mathbf{2 0}$ & $\mathbf{N}=\mathbf{2 0}$ & $13(65.0)$ \\
\hline $1-10$ & $8(40.0)$ & $12(40.0)$ & $5(25.0)$ \\
$>10$ & $6(30.0)$ & $5(16.7)$ & $3(10.0)$ \\
\hline Log-mean E. coli MPN/100 ml (SD) & $6(30.0)$ & $13(43.3)$ & $0.11(0.61)$
\end{tabular}

*Multiple responses present

${ }^{\dagger} \mathrm{NA}$ : Information not collected

Table 4: Water characteristics for intervention tubewells and household stored water

\begin{tabular}{|c|c|c|c|c|}
\hline \multirow[t]{3}{*}{ Parameters } & \multicolumn{2}{|c|}{ Tubewell water samples } & \multicolumn{2}{|c|}{ Households stored water samples } \\
\hline & Tubewell ID-13 & Tubewell ID-5 & Tubewell ID-13 & Tubewell ID-5 \\
\hline & $\mathbf{n}$ & $\mathbf{n}$ & $\mathrm{n}(\%)$ & $\mathrm{n}(\%)$ \\
\hline Concentration of iron $(\mathrm{mg} / \mathrm{L})$ & $N=6$ & $N=6$ & $N=29$ & $\mathrm{~N}=50$ \\
\hline$<1$ & 0 & 0 & $4(13.8)$ & $31(62)$ \\
\hline $1-<3$ & 0 & 6 & $8(27.6)$ & $19(38)$ \\
\hline $3-<5$ & 0 & 0 & $3(10.3)$ & 0 \\
\hline 5 or above & 6 & 0 & $14(48.3)$ & 0 \\
\hline Mean (SD) & $6.5(0.4)$ & $1.5(0.5)$ & $3.9(2.4)$ & $0.7(0.3)$ \\
\hline Average $\%$ of $\mathrm{NaOCl}$ used to treat water in the Zimba & $2.85 \%$ & $2.25 \%$ & $2.85 \%$ & $2.25 \%$ \\
\hline Free Chlorine (mg/L) & $N=160$ & $\mathrm{~N}=177$ & $\mathrm{~N}=53$ & $\mathrm{~N}=80$ \\
\hline$<0.2$ & 0 & 0 & $39(73.6)$ & $62(77.5)$ \\
\hline $0.2-2$ & $118(73.7)$ & $55(30.1)$ & $13(24.5)$ & $11(13.7)$ \\
\hline$>2$ & $42(26.2)$ & $122(68.9)$ & $1(1.9)$ & $7(8.7)$ \\
\hline Mean (mg/L) (SD) & $1.5(0.9)$ & $2.5(1.1)$ & $0.3(0.8)$ & $0.4(0.9)$ \\
\hline Total Chlorine (mg/L) & $\mathrm{N}=43$ & $\mathrm{~N}=35$ & $\mathrm{~N}=53$ & $\mathrm{~N}=80$ \\
\hline$<0.2$ & 0 & 0 & $36(67.9)$ & $57(71.2)$ \\
\hline $0.2-2$ & $25(58.1)$ & $12(34.3)$ & $16(30.2)$ & $16(2)$ \\
\hline$>2$ & $18(41.8)$ & $23(65.7)$ & $1(1.9)$ & $7(8.7)$ \\
\hline Mean $(\mathrm{mg} / \mathrm{L})(\mathrm{SD})$ & $1.8(0.8)$ & $2.4(1.0)$ & $0.43(1.1)$ & $0.53(1.1)$ \\
\hline
\end{tabular}




\section{Figures}

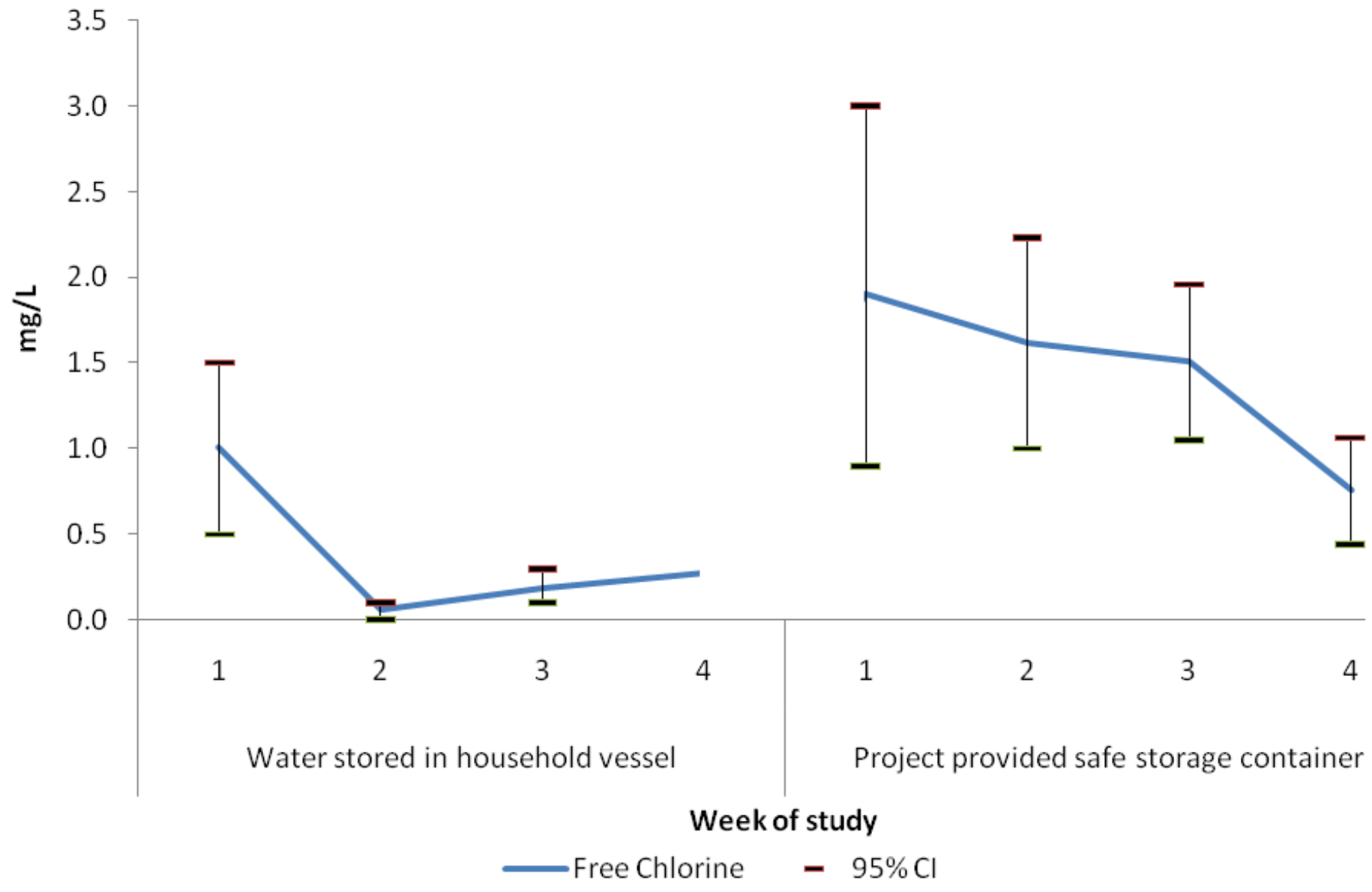

\section{Figure 1}

Weekly free residual chlorine in household storage containers and in project provided safe storage containers during follow-up visits, in FDMN-camps, Cox's Bazar, 2018.

\section{Supplementary Files}

This is a list of supplementary files associated with this preprint. Click to download.

- Supplementalinformation.docx 